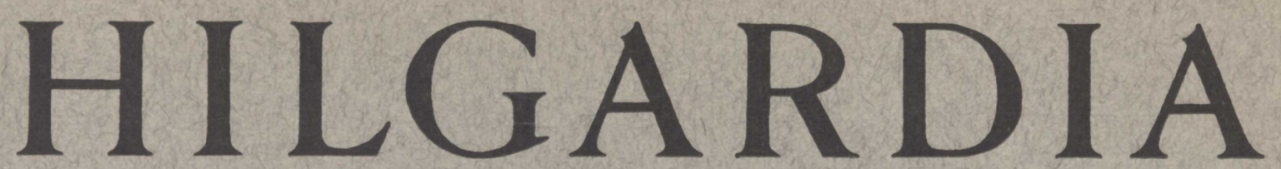

A Journal of Agricultural Science Published by the California Agricultural Experiment Station

CONTENTS

THE SUSCEPTIBILITY OF PERENNIAL DELPHINIUMS TO SIX VIRUSES

HENRY H. P. SEVERIN

\title{
LEAF VARIEGATIONS OF PERENNIAL DELPHINIUMS
}

HENRY H. P. SEVERIN

VIROSES OF ANNUAL LARKSPURS

HENRY H. P. SEVERIN

UNIVERSITY OF CALIFORNIA - BERKELEY, CALIFORNIA 


\section{LEAF VARIEGATIONS OF PERENNIAL DELPHINIUMS}

HENRY H. P. SEVERIN 



\title{
LEAF VARIEGATIONS OF PERENNIAL DELPHINIUMS
}

\author{
HENRY H. P. SEVERIN ${ }^{2}$
}

LEAF VARIEGATIONS and variegations in flowers are not uncommon among ornamental flowering plants. In perennial delphiniums two types of leaf variegations, for which the names "golden-leaf" and "silver-leaf" variegations are proposed, have been observed in seedbeds, in cold frames covered with muslin, in commercial fields of delphiniums grown for seed production and for the cut-flower trade, in nurseries, and in home gardens.

Reichert $(14)^{3}$ lists among diseases of ornamental plants in Palestine a nonparasitic yellow-leaf discoloration of Delphinium sp.

A leaf variegation somewhat similar to the leaf variegations of delphinium has become serious in certain strawberry varieties, affecting 25 to 50 per cent or all of the plants. The disease has been called "strawberry mosaic" (1), "suspected strawberry mosaic" $(2,8)$, "noninfectious chlorosis" (4), "June yellows" (11), "yellows" $(9,10)$, and "gold leaf" ( 8$)$; and at present the accepted name is "leaf variegation" $(3,5,6,7,12)$.

Berkeley (1), Guba (8), Plakidas (11), and Demaree and Darrow (7) failed to transmit leaf variegation in strawberries by insects, sap inoculations, and grafting of diseased and healthy runners, and thus presented conclusive evidence that the disease is noninfectious and not caused by a virus.

Berkeley (2) was first to suggest that leaf variegation in strawberries was of genetic origin. Clark (4) expressed the opinion that the disease was caused by a gene mutation and was hereditary. The evidence as a result of breeding work, according to Demaree and Darrow (7), suggests a sporting or mutation, which has been considered in most instances as the appearance of a recessive character in somatic tissue; they state: "Evidence so far indicates that leaf variegation is not due to a single gene. Even if by selfing no yellow plants appear, this is by no means evidence that a complimentary gene for yellowing may not be in the variety."

In the investigation of leaf variegations on perennial delphinium, the patterns on seedlings and plants growing in the field were studied; attempts were made to reproduce the variegations on delphinium seedlings

${ }^{1}$ Received for publication April 2, 1940.

${ }^{2}$ Associate Entomologist in the Experiment Station.

s Italic figures in parentheses refer to "Literature Cited" at the end of this paper. 
by mechanical inoculation and by means of different species of aphids. Virus diseases in leaf-variegated plants were studied; and transmission of leaf variegations through the seeds was tested.

\section{DESCRIPTION OF LEAF VARIEGATIONS}

Golden-Leaf Variegation.-The patterns of golden-leaf variegation resemble those of calico on second-year or older delphiniums, but the two troubles can readily be distinguished in the field. Golden-leaf variegation affects all of the leaves on a plant, including the upper or apical leaves on the stalks (plate $2, A, B$ ). The symptoms of calico are confined to the basal and intermediate leaves; the upper or apical leaves on the stalks remain green. The line and ring patterns characteristic of calico on the leaves of seedlings and perennial delphiniums described in one of the preceding papers (15) have never been observed on plants affected with golden-leaf variegation.

The most prominent and characteristic pattern of golden-leaf variegation on perennial delphiniums is the large yellow areas which extend into the lobes or divisions of the leaves (plate 1, $A$; plate $2, A$ ). When the spike and all of the leaves are cut off and the plants are given a rest period during the winter, the new leaves on the shoots may show faint, pale-yellow streaks which gradually enlarge (plate $1, B$ ) or the larger golden-yellow or pale-yellow and green areas appear immediately instead of developing from the streaks. The early stages of leaf variegation on some plants may show yellow streaks (plate 1, $C$ ). Later the leaves lose more and more of their green color and become mottled with yellow and green (plate $1, D, E$ ). The patterns vary considerably on perennial delphiniums; some show mostly streaking of the leaves (plate $2, B)$; others chiefly mottling, or a combination of both; or mostly large golden-yellow and green areas. The flowers appear normal on perennial delphiniums showing golden-leaf variegations.

Golden-leaf variegation seems to be of a systemic nature, since the new shoots which develop from the roots after a rest period show symptoms on all leaves.

Silver-Leaf Variegation.-The appearance of silver-leaf variegation is similar to the patterns of golden-leaf type except that grayish white instead of golden-yellow areas occur on the lobes or divisions of the leaves (fig. 1). Frequently delphinium seedlings show grayish-white areas with numerous, small, green dots (plate 2, $C$ ), and sometimes the lobes of a leaf from the same plant are nearly albino with chains of dots extending along the veins (plate $2, D$ ). The silver-leaf variegations are frequently found in seedbeds but are rarely found on perennial delphiniums grow- 
ing in the field. Seedlings showing silver-leaf variegations were transplanted from seedbeds in pots and were kept under observation in a glasshouse. A few of the seedlings later developed the golden-leaf patterns, but others retained the silver-leaf patterns. A delphinium plant was found near Salinas with golden-leaf variegation confined to the

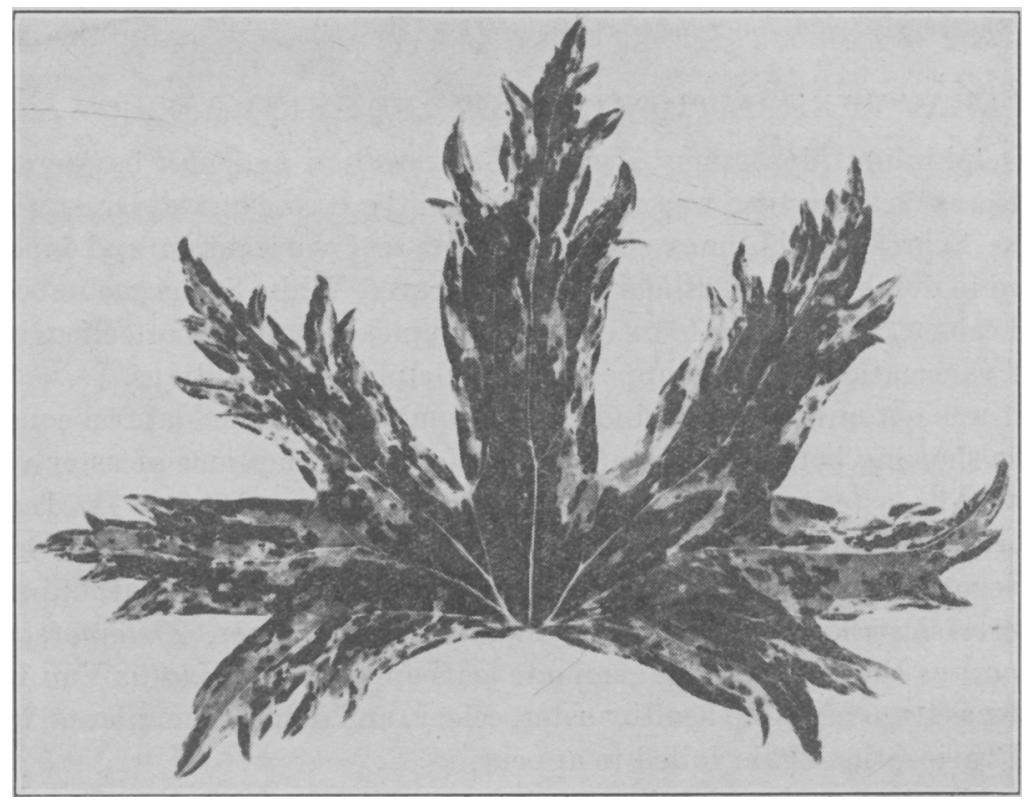

Fig. 1.-Delphinium leaf showing silver-leaf variegation with white or gray areas on the lobes.

basal and intermediate leaves and silver-leaf variegation to the upper leaves. Further investigations are necessary to determine whether the two types of leaf variegations are identical.

\section{MECHANICAL INOCULATION}

All attempts to transmit the causal agent of golden-leaf or silver-leaf variegation from 25 delphiniums by sap inoculation with the carborundum method (13) to healthy delphinium seedlings, Turkish tobaceo, Nicotiana glutinosa, White Spine cucumbers, and celery, were failures.

\section{APHIDS TESTED}

The following ten species of aphids failed to transmit the causal agent of golden-leaf or silver-leaf variegations to healthy delphiniums :

Celery leaf aphid, Aphis apigraveolens Essig

Celery aphid, Aphis apii Theobald 
Rusty-banded aphid, Aphis ferruginea-striata Essig

Cotton, or melon, aphid, Aphis gossypii Glover

Erigeron root aphid, Aphis middletonii Thomas

Yellow willow aphid, Cavariella capreae (Fabricius)

Lily aphid, Myzus circumflexus (Buckton)

Foxglove aphid, Myzus convolvuli (Kaltenbach)

Green peach aphid, Myzus persicae (Sulzer)

Honeysuckle aphid, Rhopalosiphum melliferum (Hottes)

\section{LEAF VARIEGATION, CALICO, AND ASTER YELLOWS}

Delphinium plants may show leaf variegation and also harbor the calico virus. The juice was extracted from the leaves of two Dreer's De Luxe hybrid delphiniums showing golden-leaf variegation and inoculated in delphinium seedlings, Turkish tobacco, White Spine cucumbers, and celery. These host plants developed typical symptoms of calico, but leaf variegation failed to appear on the delphinium seedlings.

It was not uncommon to find delphinium plants under natural conditions showing both golden-leaf variegation and symptoms of aster yellows. The aster-yellows virus was recovered from Dreer's De Luxe hybrid delphiniums showing a combination of aster yellows and leaf variegation by previously noninfective long-winged aster leafhoppers, Macrosteles divisus (Uhl.); the mountain leafhopper, Thamnotettix montanus Van D.; and the geminate leafhopper, T. geminatus Van D.; and was transferred to healthy aster, celery, and delphinium plants; but leaf variegation again failed to appear.

Golden-leaf variegation is sometimes associated with both calico and aster yellows in the same plant under natural conditions. The inoculum from such plants produced symptoms of calico in Turkish tobacco, White Spine cucumber, celery, and delphinium, but not leaf variegation on delphinium seedlings. The aster-yellows virus was recovered by previously noninfective long-winged aster leafhoppers and transferred to healthy asters.

\section{TRANSMISSION IN SEED}

Golden-leaf and silver-leaf variegations were found among delphinium seedlings transplanted in cold frames covered with muslin; 1 per cent of the plants developed variegations before transplanting in the field. Many delphinium varieties and hybrids were grown from seeds in cages, and both types of leaf variegations appeared on the seedlings. Seeds were planted from one delphinium plant showing golden-leaf variegation, and all of the 18 seedlings developed this type of variegation. It is evident that the causal agent of leaf variegation is seed-borne.

On the other hand, in second-year Dreer's De Luxe hybrid delphin- 
iums grown in the field, as high as 5 per cent of the plants were affected with leaf variegations. It may be possible that some delphinium seedlings develop leaf variegations after being transplanted in the field.

\section{SUMMARY}

Golden-leaf and silver-leaf variegations are nontransmissible by juice or insect inoculations and are seed-borne. They are not virus diseases.

\section{ACKNOWLEDGMENTS}

Assistance of nontechnical employees was furnished by the personnel of the Works Progress Administration Official Project No. 65-1-08-91. 
1. Berkeley, G. H.

\section{LITERATURE CITED}

1928. Strawberry mosaic. In: Güssow, H. T. Report of the Dominion Botanist [Canada] 1927:128-30.

2. Berkelex, G. H.

1931. Suspected strawberry mosaic. In: Güssow, H. T. Report of the Dominion Botanist [Canada] 1930:125-26.

3. Boyd, O. C.

1934. Leaf variegation of Blakemore strawberry in Massachusetts. The Plant Dis. Reporter. [Issued by the U. S. Bur. Plant Indus.] 18:98. (Mimeo.)

4. Clark, J. H.

1932. Noninfectious chlorosis of the strawberry. New Jersey Agr. Exp. Sta. Ann. Rept. 1930-31:279.

5. DARRow, G. M.

1934. Notes on variegated leaf trouble of strawberries. The Plant Dis. Reporter. [Issued by the U. S. Bur. Plant Indus.] 18:26-29. (Mimeo.)

6. Darrow, G. M., and J. B. Demaree.

1937. Relative importance of winter injury and some other troubles to strawberry growers in northern states. The Plant Dis. Reporter. [Issued by the U. S. Bur. Plant Indus.] 21 :392-94. (Mimeo.)

7. Demaree, J. B., and G. M. Darrow.

1937. Leaf variegation in strawberries not considered a virus disease. The Plant Dis. Reporter. [Issued by the U. S. Bur. Plant Indus.] 21:400-3. (Mimeo.)

8. GubA, E. F.

1933. "Suspected mosaic" of strawberry. Phytopathology 23:654-61.

9. Millar, P. H.

1937. Freedom from "yellows" of certain plantings of the Blakemore strawberry. The Plant Dis. Reporter. [Issued by the U. S. Bur. Plant Indus.] 21:70-71. (Mimeo.)

10. Plakidas, A. G.

1929. Report on strawberry virus project. The Plant Dis. Reporter. [Issued by the U. S. Bur. Plant Indus.] 13:129-31. (Mimeo.)

11. Plakidas, A. G.

1932. The June yellows of strawberries. Phytopathology 22:22.

12. Plakidas, A. G.

1934. Leaf variegation of the Blakemore strawberry in Louisiana. The Plant Dis. Reporter. [Issued by the U. S. Bur. Plant Indus.] 18:46-47. (Mimeo.)

13. Rawlins, T. E., and C. M. TOMPKINS.

1936. Studies on the effect of carborundum as an abrasive in plant virus inoculation. Phytopathology 26:578-87.

14. REICHERT, I.

1940. Diseases of ornamental plants. Internatl. Bul. Plant Protect. 14(10): $181 \mathrm{M}-192 \mathrm{M}$.

15. Severin, Henry H. P.

1942. Celery calico on perennial delphiniums and certain other host plants. Hilgardia 14(8) : 441-64. 


\section{PLATES}





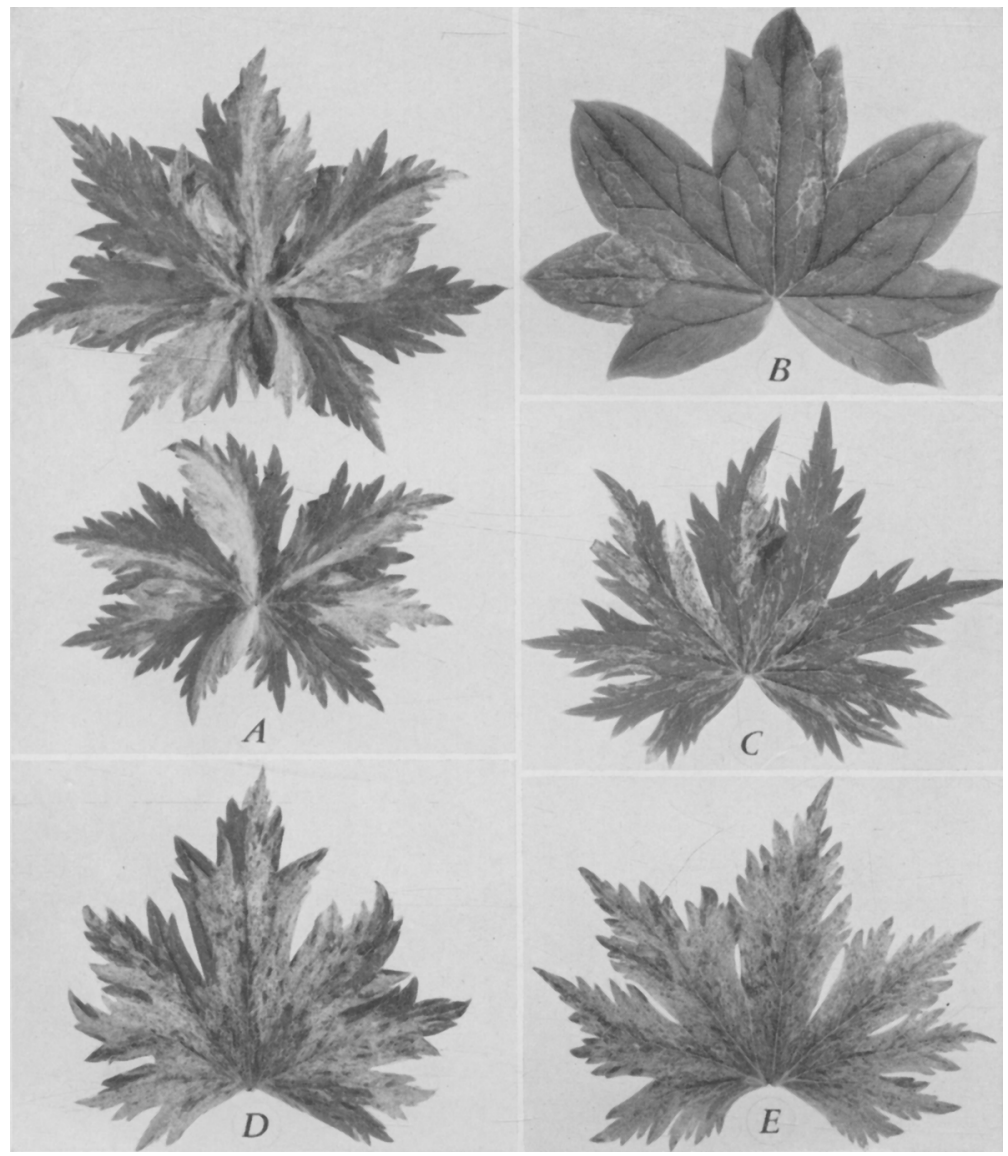

Plate 1.-Golden-leaf variegation from perennial delphiniums: $A$, large, yellow areas extending into the lobes or divisions of the leaves; $B$, faint, pale-yellow streaks on a leaf from a new shoot which grew from the roots after all of the leaves and the spike were cut off and the plant was given a rest period during the winter; $C$, yellow streaks; $D, E$, yellow and green mottling. 


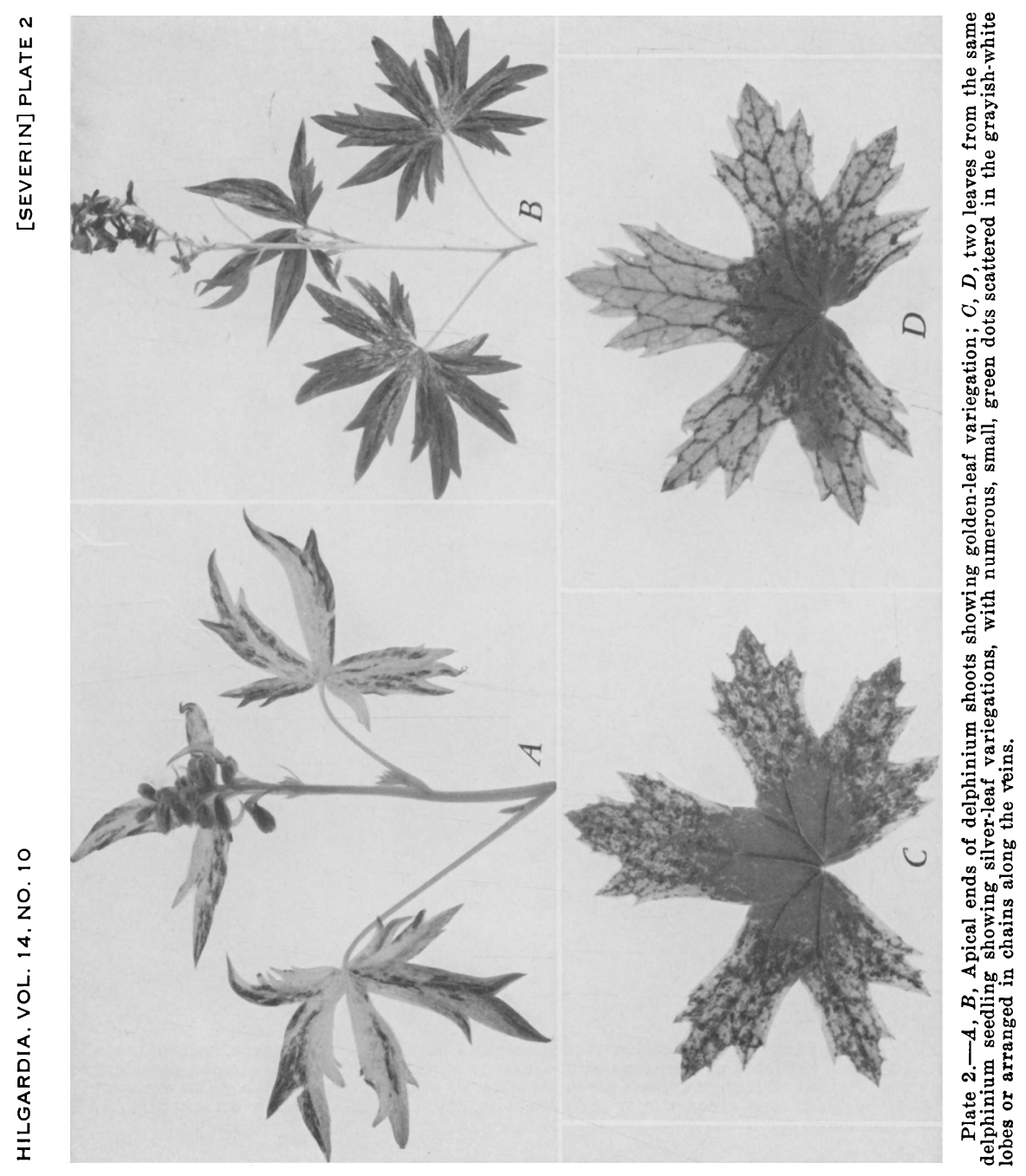

